\title{
Beta-2 Glycoprotein Antibody Measurement
}

National Cancer Institute

\section{Source}

National Cancer Institute. Beta-2 Glycoprotein Antibody Measurement. NCI Thesaurus.

Code C81979.

The determination of the amount of beta- 2 glycoprotein antibody present in a sample. 